\title{
A SYMPTOMATIC APPROACH TO SECURITIES FRAUD: THE SEC'S PROPOSED RULE 15C2-6 AND THE BOILER ROOM
}

THE rules adopted by the Securities Exchange Commission, together with regulatory measures of registered stock exchanges and dealer associations, contribute to the control of a profession involving particularly severe risks of high pressure fraud perpetrated upon an unknowledgeable clientele. The Commission, consistent with the mandate of the Securities Acts, ${ }^{1}$ has exercised its control over the profession through a regulatory framework emphasizing the need for proper disclosure of relevant information to the client about the securities to be offered or sold to him. Value is not a determinant of Commission decision. The risk is taken by the client. But to insure that the client is equipped to make his choice rationally the Commission requires that the facts facilitating that choice be disclosed, and fully and fairly stated. The purchaser who is not already informed about a stock depends upon the securities profession to perform two functions: the gathering of relevant information about the security and the transmission of this information to him so that he can make reasoned choices. Such dependence is particularly likely to exist where the transaction is initiated by solicitation on the part of a broker or dealer. If the broker or dealer, in his efforts to secure sales, either fails to investigate or misrepresents, affirmatively or by omission the information he has gathered, the unknowing or deceived client may suffer injuries from risks which he should not be considered to have assumed.

\section{BoIler Room FraUd}

Currently troubling the SEC is a particularly virulent form of fraudulent activity, the so-called "boiler room" technique," whose success and objectionability arise from its operators' failure to perform these two functions of the disclosure concept. The boiler room enjoyed its fastest growth during the inflationary period accompanying the Korean War, when new investors flooded the stock market. ${ }^{3}$ The flow of customers included a mass of credulous amateurs who proved receptive to devious sales methods of unethical dealers and brokers. The "boiler room" metaphor springs from the cacaphony and sweat created by numerous salesmen simultaneously delivering high pressure sales pitches into rows of telephones. ${ }^{4}$ Many boiler rooms have been run on an elabor-

1. Securities Act of 1933, 48 Stat. 74 (1933), 15 U.S.C. \$ 77a (1958); Securities Exchange Act of 1934, 48 Stat. 881 (1934), 15 U.S.C. \& 78a (1958).

2. A group of deceptive tactics including wild predictions of market price increases by fast talking salesmen over the long-distance telephone. 25 SEC Axs. REP. 2 (1959); Livingston, The Adrertcan Stockrolder 266 (1958). See generally SEC, Special Study of SeCurItIES MARKETS, Ch. III B, pp. 51-56, (April 3, 1963).

3. Ibid.

4. A boiler room is a small crowded office.... The drab walls are lined with desks on 
ate scale: one operation terminated by the SEC occupied fifteen rooms in which forty-seven salesmen and clerks ran up a telephone bill of $\$ 40,000$ a month on fifty telephones. ${ }^{5}$ But most boiler rooms are not so ambitiously staffed or supplied $;^{6}$ all that is necessary to achieve breadth of operation is the telephone. ${ }^{7}$ Success is based on fast turnover at inflated prices. The operators conducting the schemes deal exclusively in low-priced, little known stocks. ${ }^{8}$ They make no effort to give prospective customers accurate information on which to base a reasonable

which sit telephones, shrouded with hoods. On the table are out-of-town telephone books. ... As soon as a prospect is nibbling, the salesman ducks his head under the hood to block out the chatter of other hard-pushing salesmen. Thus he can talk real quiet and confidential-like.

Lrvingston, op. cit. supra note 2 , at 266 . The attempt to diminish noise by makeshift methods appears to be a characteristic of intense boiler room campaigns. Another ludicrous setting is described:

On each desk sat a wooden packing crate, upended, with a telephone inside each crate. A salesman would sit with head and shoulders inside the crate, telephoning potential suckers all over the United States.

Coraiter, Wall Street's Shady Stde 167 (1962), regarding a notorious boiler room sales operation reported in Great Sweet Grass Oils Ltd., 37 SEC 683 (1957). For a report of the "wooden cubicles" used in a Canadian operation see Timbers \& Pollack, Extraditions fram Canada to the United States for Securities Frand: Frustration of the National Palicics of Both Countries, 24 FoRdHAM L. REv. 301, 314 n.80 (1955).

But boiler room facilities need not be limited to the crowded, cellular type described above. Not infrequently salesmen make their calls from hotel rooms and apartments, 25 SEC ANN. REP. 3 (1959), and it would be possible to carry on a boiler room campaign from a brokerage with ordinary physical characteristics, cf. note $31,2 \mathrm{~d}$ para., infra.

5. Great Sweet Grass Oils Ltd., 37 SEC 683, 687 (1957). In addition to telephone expenses, the monthly postage costs to the broker averaged $\$ 3,200$. Ibid. Barnett \& Co., SEC Securities Exchange Act Release No. 6310, July 5, 1960, p. 3, n.3 (telephone bill of $\$ 3,000$ and $\$ 6,000$ for two months); Midland Sec., Inc., SEC Securities Exchange Act Release No. 6524 , April 10, 1961, p. 3, n.3 (telephone bill over twenty-two month period almost $\$ 50,000$ ). The high operating expenses of boiler rooms are considered by the SEC to be significantly responsible for increasing high-pressure and misleading selling methods which "are almost essential if a sufficient number of sales are to be made, at prices sufficiently above the cost of doing business, so as to result in a profitable operation." SEC Securities Exchange Act Release No. 6885, Aug. 16, 1962, p. 3.

6. See 25 SEC Ann. Rep. 3 (1959). See also Wall Street Journal, May 21, 1962, p. 3, col. 2 .

7. In one operation sales were made over the phone to "all sections of the country and in practically every state. ..." Best Sec., Inc., SEC Securities Exchange Act Relcase No. 6282, June 3, 1960, p. 3. Midland Sec. Inc., SEC Securities Exchange Act Release No. 6524, April 10, 1960, p. 3 ("throughout the United States") ; Keith Richard Sec. Corp., SEC Securities Exchange Act Release No. 5988, June 17, 1959, p. 4 ("in at least 30 states"). In D.H. Victor \& Co., SEC Securities Exchange Act Release No. 6562, May 17, 1961, p. 3, six out-of-state witnesses testified, and in Biltmore Sec. Corp., SEC Securities Exchange Act Release No. 6394, Oct. 17, 1960, p. 3, five appeared. The wide range of boiler room operations and the necessity of contacting witnesses in several different states highlight difficulties and expenses of acquiring proof in boiler room cases. See 22 SEC ANN. RE1, 3 (1956).

8. Mac Robbins \& Co., SEC Securities Exchange Act Release No. 6846, July 11, 1962, p. 4. 
decision, ${ }^{9}$ and they may not have bothered even to secure the information for themselves $;^{10}$ instead, they use the psychological pressure of long distance calls and selling techniques designed to encourage hasty decisions founded on groundless promises of quick profits. ${ }^{11}$ The psychological impact is heightened by selection of stocks from glamour industries: drugs, ${ }^{12}$ communications and electronics, ${ }^{13}$ plastics, ${ }^{14}$ oil, ${ }^{15}$ uranium, ${ }^{16}$ mining and exploration, ${ }^{17}$ aircraft, ${ }^{18}$ and bowling alleys. ${ }^{19}$

The sales campaign typically begins with the distribution of brochures, 20

9. Sometimes the information is not available from sources other than the issuing company. For instance, in Theodore A. Landau, SEC Securities Exchange Act Relcase No. 6792, Apr. 30 1962, the broker sold unregistered securities in violation of $\$ 5$ of the Securities Act, 48 Stat. 77 (1954), as amended, 15 U.S.C. § 77e (1958).

10. E.g., Mac Robbins \& Co., SEC Securities Exchange Act Release No. 6346, July 11, 1962 , p. 4 , in which salesmen said they were unaware of losses sustained by the issuing company in whose securities they were specializing.

11. Best Sec., Inc., SEC Securities Exchange Act Release No. 6282, June 3, 1960, p. 3.

12. N. Pinsker \& Co., SEC Securities Exchange Act Release No. 6401, Oct. 21, 1980.

13. Barnett \& Co., SEC Securities Exchange Act Release No. 6310, July 5, 1960 (television antennas) ; Alexander Reid \& Co., SEC Securities Exchange Act Release No. 6727, Feb. 8, 1962 (machine designed to transmit facsimile of documents over telephone wires); Best Sec., Inc., SEC Securities Exchange Act Release No. 6282, June 3, 1960 (telephone company).

14. Keith Richard Sec. Corp., SEC Securities Exchange Act Release No. 5985, June 17, 1959.

15. A.G. Bellin Sec. Corp., SEC Securities Exchange Act Release No. 5966, MIay 18, 1959; Leonard Burton Corp., SEC Securities Exchange Act Release No. 5978, Junc 4, 1959; Midland Sec. Inc., SEC Securities Exchange Act Release No. 6524, April 10, 1961 ; D.H. Victor \& Co., SEC Securities Exchange Act Release No. 6562, MIay 17, 1961.

16. W.T. Anderson Co., SEC Securities Exchange Act Release No. 6177, Feb. 9, 1960. 1961.

17. N. Sims Organ \& Co., SEC Securities Exchange Act Release No. 6495, AFarch 14,

18. SEC v. Rapp, 304 F.2d 786 (2d Cir. 1962).

19. Mac Robbins \& Co., SEC Securities Exchange Act Release No. 6846, July 11, 1962.

The use of the glamour industry as a lure is, of course, not merely a contemporary phenomenon. As the 1925 President of the New York Stock Exchange commented on securities swindles,

Every successful new invention-the automobile, the radio or the latest electrical device-is immediately seized upon by a swarm of promoters whose only desire is to unload fradulent securities on a wave of public enthusiasm. The outward forms adopted by swindlers to camouflage their operations are continually changing. One year the public is invited to sink its savings in alleged oil drillings, or new inventions, or foreign exchange trading. The next year it may be land speculation, rotten mortgages, wildcat mining ventures, or security and commodity bucketshops. Yet, under all these outward and rapidly changing forms, the swindling evil itself persists and even grows stronger in the land from year to year.

Starmons, Cooperation Against Security Frauds 29 (1925).

20. Mac Robbins \& Co., supra note 19, at 5. Newspaper advertising is also used. SEC v. Seipel, CCH FEd. SEC. L. REp. I 90735, p. 2 (D.D.C. Oct. 11, 1954), aff'd per curiam, 229 F.2d 758 (D.C. Cir. 1955) ; United States v. Rollnick, 91 F.2d 911, 915 (2d Cir. 1937). Newspaper columnists and market advisory services have also been induced to stoke the boiler room fires by writing optimistic reports of issues. Wise, The World of Alsxander Guterma, Fortune Magazine, Dec. 1959, 144, 148. 
occasionally prepared by advertising firms, ${ }^{21}$ intended to create an inflated impression of the prospects of the issuing company. The brochures are mailed to persons whose names are selected at random from out-of-town telephone books ${ }^{22}$ or appear on lists purchased from directory concerns or mail list specialists. ${ }^{23}$ Favored lists contain names of doctors, farmers, small businessmen, housewives, teachers, and widows. ${ }^{24}$ The second step, in what has been called a "'boiler room' blitz,"25 is a telephone call to the brochure recipient by a salesman-known to his associates as a "coxey" or "opener" "20_who generally makes preliminary statements exaggerating the prospects of the stock advertised in the brochure. ${ }^{27}$ Following this opening move a second salesman - the "loader" or "dynamiter"28_may take over and attempt to convey the impression that he is an experienced broker whom the buyer can trust. Occasionally a third salesman - the "reloader"20_will follow up a completed sale by encouraging the customer to make additional purchases. Although the salesmen involved represent themselves as experienced brokers, intimately acquainted with the company whose stock they offer and concerned with the buyer's investment needs, the claimed expertise and concern are not demonstrated by their actions. Often the salesmen have had no previous experience either with securities or business generally, ${ }^{30}$ and receive limited training and

21. Albion Securities Co., Official Report of Proceedings Before the SEC; Special Study of the Securities Market 1290, May 18, 1962.

22. LIVINGSTON, op. cit. supra note 2, at 266.

23. Great Sweet Grass Oils Ltd., 37 SEC 683, 687 (1957); Albion Securities Co., supra note 21, at 1285.

24. Albion Securities Co., stura note 21, at 1285-86; 22 Sec. ANN. REp. 4 (1956) Cormier, op. cit. supra note 4, at 163; Klaw, The Great Swect Grass Swindle, Fortune Magazine, Aug. 1957, 134, 135.

25. Kahn v. SEC, 297 F.2d 112, 115 (2d Cir. 1961).

26. Klaw, sitpra note 24 , at 175 .

27. In the Sweet Grass sales campaign the "coxey" was given a canned sales pitch: ...Mr. Smith, as sure as I am talking with you on this telephone this stock will reach ten to twelve dollars in the next sixty to ninety days.... I am putting my clicnts into Great Sweet Grass and many of these people have been with me for the past fourteen years. ... I beg of you for 1 per cent of your confidence; I promise I will earn the other 99 per cent.

Ibid. For excerpts from another conversation between "coxey" and customer, see CormuEk, op. cit. supra note 4, at 164-65.

28. Klaw, supra note 24, at 175. See Windels, Our Securities Markcts-Some SEC Problems and Techniques, 8 N.Y.L.F. 169, 178 (1962).

29. Timbers \& Pollack, stipra note 4 , at 314 .

30. In SEC v. Rapp, 304 F.2d 786 (2d Cir. 1962), it was held that the broker "hired men with no knowledge of the intricate business of securities ... thereby ensuring that the accuracy of their representations would be wholly fortuitous. . ." Id, at 790. In Albion Securities Co., supra note 21 , salesmen were trained by reporting to the office and listening to other salesmen for a week or two, and supervision appeared to be concerned exclusively with their high-pressure technique. See $i d$. at 1278. See generally Wall Street Journal, May 21, 1962, p. 5, col. 2 and Aug. 17, 1962, p. 6, col. 1. For a full study of the qualifications of securities salesmen, see SEC, Special Study of Securuties Markets, ch. II C, (April 3, 
supervision beyond boiler room technique. ${ }^{31}$ Common misrepresentations by these supersalesmen include unfounded predictions of price increases, ${ }^{32}$ extravagant exaggerations of facts concerning the product, ${ }^{33}$ hints of unnamed developments, ${ }^{34}$ half truths used to distort material information, ${ }^{35}$ groundless statements of impending mergers ${ }^{36}$ or imminent listings on a national ex-

1963). For a review of recent state regulatory measures directed at this problem, see Lefkowitz, New York: Criminal Infiltration of the Securities Industry, Annals, Mfay, 1963, p. 51.

31. J. Logan \& Co., SEC Securities Exchange Act Release No. 6848, July 9, 1962. Sce Albion Securities Co., supra note 21, at 1278. For an analysis of training by firms not members of the New York Stock Exchange, see SEC, Spectal Study of Securrtres Miarkets, ch. II C, 35-47, (April 3, 1963).

Presumably because of the increase in branch operations, supervision is lax cren among major members of the New York Stock Exchange. Aferrill Lynch, Pierce, Fenner \& Smith became involved in a sale of securities in the spring of 1961 that has many of the markings of a boiler room operation. Merrill Lynch, Pierce, Fenner \& Smith, Inc, Official Report of Proceedings Before the SEC; Special Study of the Securities Mrarket 832, Mlay 16 , 1962. In response to a full page advertisement in the Los Angeles Mfirror regarding a company, Aquafilter, which manufactured a cigarette filter that was supposed to "excel all others" in the removal of tars and nicotine, a Mierrill Lynch account executive contacted the firm. After attending a cocktail party given by Aquafilter for "members of the financial community," he and other salesmen began to push Aquafilter stock aggressively. Id. at 908-09. The salesmen claimed that there was a plant producing filters in Connecticut, and that net profits would increase considerably in a short time. Id. at 923. Actually there vas no plant, and the salesmen had no information on which to base their speculations. Wall Street Journal, May 17, 1962, p. 32, col. 1. The over-the-counter price of Aquafilter, which had risen from $\$ 25$ to $\$ 6.50$ during the Merrill Lynch campaign, fell to $\$ 50$. Ibid.

32. Bilmore Sec. Corp., SEC Securities Exchange Act Release No. 6394, Oct. 17, 1980, p. 3 (prediction that stock price "would go up to about six points' that crening" from between 11/4 and 13/4); Alexander Reid \& Co., SEC Securities Exchange Act Release No. 6727, Feb. 8,1962, p. 3 (that stock would rise from below $\$ 2$ to as high as $\$ 20$ within a year). In these and many similar cases the issuing companies showed operating losses and little promise that their market price would rise without stimulation from the boiler room.

33. N. Pinsker \& Co., SEC Securities Exchange Act Release No. 6401, Oct. 21, 1960, pp. 5-6 (salesmen made groundless claims of the development of "another wonder drug" by the issuer, and of a "cure for cancer which would be publicly announced as soon as confirmation was received from Denmark"); Midland Sec. Co., SEC Securities Exchange Act Release No. 6524, April 10, 1961, p. 4-5 (salesmen claimed that the issuer, a petroleum company, had just "brought in a 'gusher.' "In fact, the wells were producing only a trickle and almost no income).

34. Biltmore Sec. Corp., SEC Securities Exchange Act Release No. 6394, Oct. 17, 1960 , p. 3 ("something is brewing") ; Alexander Reid \& Co., SEC Securities Exchange Act Release No. 6727, Feb. 8, 1962, p. 3 (salesman reported that "'tremendous things' vere happening," but that he was sworn to secrecy).

35. E.g., Midland Sec. Co., SEC Securities Exchange Act Release No. 6524, April 10, 1961, pp. 3-4, in which a salesman told a customer that the issuer had acquired oil and gas rights in or near Canadian oil fields, but failed to add that the company's holdings had undergone constant reduction and resulted in practically no income.

36. E.g., N. Pinsker \& Co., SEC Securities Exchange Act Release No. 6401, Oct 21, 1960, p. 5; Best Sec., Inc., SEC Securities Exchange Act Release No. 6282, June 3, 1960, p.3. 
change, ${ }^{37}$ and unqualified material misstatements. ${ }^{38}$ In sum, there is ustually a failure to disclose and a failure to investigate; the salesmen frequently know little about the stock they are selling and care even less about their clients' financial needs. ${ }^{39}$

\section{Present SEC Controls}

To combat these undesirable sales tactics the Commission and the courts have relied upon the anti-fraud provisions of the Securities Acts. Under these sections it is unlawful, in connection with an offer or sale of securities in interstate commerce, to obtain money or property by making

any untrue statement of a material fact or any omission to state a material fact necessary in order to make the statements made, in the light of the circumstances under which they were made, not misleading. . . .40

The earliest cases under the anti-fraud provisions held there is an implied representation by a broker or dealer that he will deal fairly with his customers in accordance with the standards of the profession. $\mathbf{4 1}$

Beginning in the mid-1950's, the SEC began an enforcement campaign specifically directed at applying these concepts of fair dealing to the growing problem of boiler rooms. ${ }^{42}$ The Commission was aided, moreover, by the

37. E.g., A.G. Bellin Sec. Corp., SEC Securities Exchange Act Release No. 5966, May 18, 1959, p. 5; Peerless-New York, Inc., SEC Securities Exchange Act Release No. 6193, p. 3, Feb. 26, 1960.

38. SEC v. Rapp, 304 F.2d 786 (2d Cir. 1962), and Midland Sec., Inc., SEC Sccuritics Exchange Act Release No. 6524, April 10, 1961, p. 4 (salesmen falsely claimed that the issuers had or were about to receive government contracts); D.H. Victor \& Co., SEC Securities Exchange Act Release No. 6562, May 17, 1961, p. 3 (that issuer was already paying dividends); N. Sims Organ \& Co., SEC Securities Exchange Act Release No. 6495, March 14, 1961, p. 3 (that brokerage had been in business for 27-28 years, while actually it had been in business for less than three years).

39. E.g., Barnett \& Co., SEC Securities Exchange Act Release No. 6310, July 5, 1960, p. 4.

40. Section 17 (a) of the Securities Act of 1933, 48 Stat. 84 (1933), 15 U.S.C. \& $77 q(a)(2)(1958)$. Other anti-fraud provisions applied in boiler room cases include Securities Exchange Act of 1934 \& 10(b), 48 Stat. 891 (1934), 15 U.S.C. \& 78j(b) (1958) and \& 15 (c) (1), 48 Stat. 895 (1934), 15 U.S.C. $\$ 780$ (c) (1) (1958), and Rules 10b-5 and 15c1-2 [17 CFR 240.10b-5 and 15c1-2 (1949)] thereunder. The provisions are similar in language, but are distinguished by their coverage. Section 17 (a) refers to "offer or sale," whilo \& 10b-5 to "purchase or sale." Section 15(c) (1) applies specifically to brokers and dealcrs, while $\S 17(a)$ and Rule $10(\mathrm{~b})$ extend to "any person." See generally 3 Loss, Secunurtes RegULATtON 1421-30 (2d ed. 1961).

41. Duker \& Duker, 6 S.E.C. 386, 388-89 (1939). Succeeding cases applied the concept of fair dealing to specific activities. E.g., Charles Hughes \& Co. v. SEC, 139 F.2d 434 (2d Cir. 1943), in which it was held that it was not fair dealing for brokers to charge customers prices unrelated to the prevailing market price. See generally 3 Loss, op. cit. silpra note 40 , at $1482-93$.

42. Although there are isolated cases before the 1950's, e.g., U.S. v. Rollnick, 91 F.2d 111 (2d Cir. 1937), the boiler room problem and SEC attempts at control appear to have become most intense during the past decade. In 1956 the SEC estimated that there were 40 
broad interpretation of fraud in the securities field, an interpretation stemming from the "intricate merchandise" 43 character of securities and the dearth of relevant knowledge the usual client possesses. 4 The boiler room practices which the Commission and the courts found to be prohibited by the anti-fraud provisions included predictions without an adequate basis, 10 knowing misstatements, ${ }^{46}$ omission to state material facts, ${ }^{47}$ and reckless repetition of unverified self-serving statements of issuers. 48 "Fair dealing" thus would seem to include elements of both duty to investigate and duty to inform on the part of the dealer or broker.

Enforcement difficulties have arisen, however, in detecting and proving violations. Since potential witnesses are spread throughout the country, ${ }^{\text {t9 }}$ the administrative difficulty and costs of investigating boiler room cases are particularly great. The Commission's normal method of governing broker-dealers is by a program of periodic inspection. ${ }^{50}$ Further inspections may result from the investor complaints which constitute a major source of information about violations. ${ }^{51}$ During fiscal year 1961, however, the SEC inspected less than one-third of the more than 5,000 practicing broker-dealers. ${ }^{82}$ Although this

boiler rooms operating in New York City, employing a total of between 400 and 500 salesmen. Klaw, supra note 24, at 135 . While boiler room activity may have reached its peal: in the late 1950's, N.Y. Herald Tribune, Aug. 17, 1962, p. 20, col. 6, there have been more than thirty boiler room revocation and suspension rulings rendered by the SEC since January, 1960, Wall Street Journal, Aug. 17, 1962, p. 6, col. 1.

In many of the cases during the early part of this period, the securities that reached the boiler rooms for peddling to the public already had a history of devious and illicit promotion. See generally Great Sweet Grass Oils Ltd., 37 S.E.C. 683 (1957); CoranER, op. cir. stipra note 4, at 159-72; Wise, The World of Alexanter Guterma, Fortune, Dec. 1959, 144; Klaw, The World of Lowell Birrell, Fortune, Nov. 1959, 170; Klaw, The Great Srece! Grass Swindle, Fortune, Aug. 1957, 134. The issuer frauds appear to have been successfully controlled. CoRsrrer, op. cit. supra note 4, at 171.

In New York, state authorities, both legislative and executive, have also been engaged in stepped-up enforcement campaign against the boiler room. Leflowitz, New Yorl: Criminal Infiltration of the Securities Industry, Annals, MFay, 1963, p. 51.

43. H.R. REP. No. 85, 73d Cong., 1st Sess. 8 (1933).

44. See Archer v. SEC, 133 F.2d 795, 803 (8th Cir. 1943); Charles Hughes \& Co. v. SEC, 139 F.2d 434, 437 (2d Cir. 1943), cert. dented, 321 U.S. 786 (1944); 3 Loss, op. cir. supra note 40 , at 1435.

45. See cases cited in note 37 supra.

46. E.g., Biltmore Sec. Corp., SEC Securities Exchange Act Release No. 6394, Oct. 17, 1960; Leonard Burton Corp., SEC Securities Exchange Act Release No. 5978, June 4, 1959, p. 5.

47. E.g., N. Pinsker \& Co., SEC Securities Exchange Act Release No. 6401, Oct. 21, 1960, p. 7.

48. E.g., Best Sec, Inc, SEC Securities Exchange Act Release No. 6282, June 3, 1960; Barnett \& Co., SEC Securities Exchange Act Release No. 6310, July 5, 1960.

49. See note 7 supra.

50. Loomis, Enforcement Problems Under the Federal Securities Laus, 14 Bus. Law. $665,674(1959)$.

51. SEC, Spectal Study of Securities Markets, ch. III B, 134, April 3, 1963.

52. 27 SEC AnN. Rep. 4-5 (1961). 
program has expanded during the past few years, ${ }^{53}$ it has been unable to match the vast increase in investors, securities salesmen, and branch operations. ${ }^{\text {at }}$ Furthermore, the problems of proof of violation once inspection has occurred are considerable; in order to establish evidence of boiler room misrepresentintion, it is necessary not only to ascertain what was communicated, but also "to tie back those representations made by voice over the long-distance telephone to the boiler room, and to assemble some evidence concerning the issuer in order to make a showing as to the false or misleading character of the representations." 55 In addition to these problems of proof, the Commission has had difficulty in convincing appellate judges that salesmen employing boiler room tactics violated the Securities Acts. ${ }^{56}$

\section{Proposed Rule 15c2-6}

Because of the difficulties of continuing its program of halting boiler room activities by this protracted adjudicatory method, the Commission is in the process of developing, by exercise of its rule-making power, other means for the elimination of the boiler room. Proposed Rule $15 c 2-6^{67}$ wottd seek to avoid administrative proof problems by interdiction of a general course of business which, though in itself not necessarily illegal, is identified by the SEC as a

53. Id. at 1-2; Wall Street Journal, May 8, 1962, p. 3, col. 2.

54. 27 SEC ANN. REp. 4-5 (1961).

55. Loomis, supra note 50, at 673 ; Windels, supra note 28, at 178. Furthermore, since "inspectors mostly confine their activities to an examination of books and records and do not routinely uncover evidence of misrepresentation or high pressure in the sale of securities, as they do not generally listen to the sales presentation or question any customers." SEC, Spectal Study of Securities Markets, ch. III B, 135-36, April 3, 1963.

Another problem is lack of coordination between enforcement agencies, particularly those of the various states and the National Association of Securities Dealers. Some state security law administrators have claimed that their enforcement procedures were hampered by the NASD's refusal to supply information the Association had already gathered. Duplication of effort by the various agencies has also been criticized. Wall Street Journal, May 22, 1962, p. 2, col. 2. For a discussion of international enforcement difficulties, see Timbers \& Pollack, supra note 4; CoRMIER, supra note 4, at 168-71; 26 SEC ANN. Rep. 202-04 (1960). The international problems appear to be decreasing. 27 SEc. AnN. REP. 174-75 (1961). Sce generally Loomis, op. cit. supra note 50, and Wall Street Journal, April 13, 1962, p. 5, col. 2; April 30, 1962, p. 5, col. 2; May 8, 1962, p. 3, col. 1; May 17, 1962, p. 32, col. 1; May 24, 1962, p. 5, col. 1; May 28, 1962, p. 28, col. 1 .

56. Remand by a federal court to an administrative agency for clarification of the agency's opinion is not unusual. In a peak period of boiler room activity, however, timeconsuming exchanges of administrative and judicial opinions had a burdensome effect on the SEC enforcement effort. One case, in which the SEC suspended a securities salesman, who had been involved in a boiler room operation, for making predictions without an atlequate basis, was on appeal, on remand and in the process of rewriting, and again on appeal for over two years. It was recently affirmed. Mac Robbins \& Co., SEC Securities Excinnge Act Releases No. 6462, Feb. 6, 1961, and 6498, March 16, 1961; Berko v. SEC, 297 F.2d 116 (2d Cir. 1961) ; Mac Robbins \& Co., SEC Securities Exchange Act Release No. 6846, July 11, 1962, aff'd Berko v. SEC, No. 27774, 2d Cir., April 9, 1963. See also Kahn v. SEC, 297 F.2d 112 (2d Cir. 1961) ; SEC v. Rapp, 304 F.2d 786, 791 (2d Cir. 1962).

57. SEC Securities Exchange Act Release No. 6885, Aug. 16, 1962. 
usual incident of fraudulent transactions. ${ }^{58}$ The rule 58 would make it unlawful for a broker or a dealer to offer or sell certain equity securities at a price of $\$ 10$ or less by telephone unless he establishes that the transaction is exempt under the rule. Once it were shown that non-exempt securities were involved in such

58. The rule would be adopted pursuant to Section $15(c)$ (2) of the Securities Exchange Act, authorizing the SEC to make rules to

define ... and prescribe means reasonably designed to prevent such acts and practices as are fraudulent, deceptive, or manipulative and such quotations as are fictitious. 48 Stat. 895 (1934), 15 U.S.C. § 78o(c) (2) (1958).

59. Proposed Rule 15c2-6, SEC Securities Exchange Act Release No. 6885, Aug. 16, 1962:

(a) It shall constitute a "fraudulent, deceptive or manipulative act or practice" within the meaning of Section 15(c) (2) of the Act for any broker or dealer to offer or sell any equity security at a price of $\$ 10$ or less by telephone to any person other than a broker, dealer, institutional customer or regular customer, unless such broker or dealer establishes that either the security or the transaction falls within one of the following categories of securities or transactions:

(1) Any security, the issuer of which (A) has, as evidenced by a profit and loss statement certified by an independent public accountant, had net income in its most recent fiscal year or, if such fiscal year ended within 120 days prior to the offer or sale of such security by the broker or dealer and a certified profit and loss statement is not available, the last preceding fiscal year, and (B) is either currently filing reports pursuant to Sections 13 or 15 (d) of the Act, or Section 14 of the Public Utility Holding Company Act of 1935, or Section 30 of the Investment Company Act of 1940 , or is a company in respect of which there is published in a recognized securities manual a list of the names of the issuer's officers and directors, a balance sheet as of a date within 16 months of the offering or sale, and a profit and loss statement for either the fiscal year ending on that date or the most recent fiscal year. Such balance sheet and profit and loss statcment must have been certified by an independent public accountant, but it shall not be a requirement that the certificate of such accountant be contained in any such securities manual;

(2) Isolated transactions not a part of any concentrated sales efforts by the broker-dealer; or

(3) A transaction which is not solicited by the broker or dealer; or

(4) A security registered under the Securities Act of 1933, which is offered or sold at a time when delivery of a prospectus is required by Section 5 thereof, and as to which a prospectus meeting the requirements of that Act is delivered to the purchaser in accordance with the provisions of that Act.

(b) The prohibitions of paragraph (a) of this rule shall not apply to any specific transaction which, upon prior written request, the Commission exempts as not being comprehended within the purposes of this rule.

(c) For the purposes of this rule:

(1) The term "institutional customer" means a bank; a trust company; an insurance company; a pension, welfare, profit sharing or similar fund; an investment company registered under the Investment Company Act of 1940; or any other similar financial institution.

(2) The term "regular customer" means any person with whose written agreement the broker or dealer is maintaining a general account or special cash account as provided in Regulation $T$, and who has purchased securities of two or more different issuers at different times within the past year from or through 
a transaction-a showing itself facilitated by the rule's new and extensive record-keeping requirements-the alleged offender would have the burden of proving his acts not to have been subject to the rule. Exemptions are specified for transactions which involve brokers, dealers, institutional customers or "regular customers" or else are isolated, unsolicited, or involve certain securities which are either registered or described in a "recognized" investment manual. If the proscribed activities occur, the broker's registration may be revoked ${ }^{60}$ and the salesman may be suspended from the practice of selling securities. 01

Strong criticism that the proposed rule casts its net too broadly has been

such broker or dealer in such accounts, unless such purchases have been solicitcd to avoid the operation of this rule.

(3) The term "recognized securities manual" means a securities manual which has been published continuously for a period of 5 years or more prior to the offer or sale by an investment adviser registered as such under the Investment Advisers Act of 1940.

(d) Every broker or dealer shall maintain the following and records with regard to transactions in any equity security offered or sold by telephone at a price of $\$ 10$ or less to any person other than a broker, dealer, institutional customer or regular customer :

(1) A separate daily record for each person connected with such broker or dealer who offered or sold the security showing: $(A)$ the date and time of each such telephone call, (B) the name of the person connected with such broker or dealer who offered the security to the customer or prospective customer, and the telephone number and location of the telephone used by such person, (C) the name, address and telephone number of the customer or prospective customer to whom the security was offered, (D) whether such telephone call was initiated by such broker or dealer or by the customer or prospective customer, (E) the title and price of the security offered, and (F) the number of shares, or units, if any, purchased by the customer and the price thereof. Such record shall be signed by the person whose offers and sales are recorded thereon, and shall be approved and signed by a partner, officer, or office manager of such broker or dealer, or by such broker or dealer if a sole proprietor.

(2) A copy of every list of names, any part of which is used by any person connected with such broker or dealer in identifying customers or prospective customers to whom securities might be offered or sold, which copy shall also indicate the source of any such list.

(3) Copies of all telephone toll slips reflecting all toll telephone calls charged to such broker or dealer.

The provisions of paragraph (d) of this rule shall not apply to:

(1) any transaction executed on a national securities exchange, or

(2) the offering or sale of a security registered under the Securities Act of 1933 which is offered or sold at a time when delivery of a prospectus is required by Section 5 thereof, and as to which a prospectus meeting the requirements of that Act is delivered to the purchaser in accordance with the requirements of that Act.

60. Securities Exchange Act of 1934 § 15(b), 49 Stat. 1378 (1936), 15 U.S.C. $\S 780$ (b) (1958). He may be suspended or expelled from a registered securities association under Securities Exchange Act of $1934 \S 15 A(1)$ (2), 52 Stat. 1070 (1938), as amended, 15 U.S.C. § 780-3(b) (8) (1958).

61. Securities Exchange Act of $1934 \S 15 \mathrm{~A}(\mathrm{~b})(4), 52$ Stat. 1070 (1938), as amended, 15 U.S.C. $\$ 780-3$ (b) (4) (1958). 
voiced by the securities industry and other interested parties. ${ }^{\text {c2 }}$ It is charged that a symptomatic approach, which focuses rigidly upon telephone sales of low-priced stock-a mode of transaction common to all securities sellers-and requires burdensome record-keeping efforts, may affect legitimate as well as illegitimate business as a result of favoring expediency of proof over functional concern for discriminate enforcement.

Taken without its exemptions, the regulation, making any telephoned offer to sell an equity security at a price of $\$ 10$ or less a "fraudulent, deceptive or manipulative act or practice,"03 covers a vast number of ordinary, non-fraudulent sales and practices. The $\$ 10$ or less cutoff price doubtless includes the great majority of boiler room offerings, but it also reaches many investments not normally subject to the fraudulent practices sought to be outlawed by the rule. ${ }^{64}$ And the telephone is one of the modern securities salesman's most essential tools, offering him both speed of communication suitable for a rapidly fluctuating market and a form of personal approach invaluable as a sales technique. Assuming that attempts to evade coverage by unit sales ${ }^{\mathrm{cs}}$ or by injection of non-telephonic approaches into the sales campaign can be frustrated through a liberal construction of the rule, the resultant inclusiveness might have a detrimental impact on legitimate market activity. Restrictions on telephone sales would doubtless reduce turnover, and, hence, interest and price of all securities in the affected range. ${ }^{8 B}$ Not only might individual issues suffer unnatural declines in market price due to discrimination resulting from the rule, but the general activity of the market, particularly with respect to the traditionally low-priced issues of new companies seeking venture capital, might also be made more sluggish. The expense in time and effort in conforming to the new and extensive bookkeeping provisions ${ }^{07}$ might contribute further to these depressing effects. Presumably in order to avoid these effects while achieving evidentiary benefits, the proposed rule attempts to exempt situations not normally subject to boiler room techniques: securities presenting relatively less danger of exploitation, persons less likely to be exploited, and circumstances in which enforcement is not worth the cost.

62. E.g., Letters to the SEC from Wallace H. Fulton, Executive Director, National Association of Securities Dealers, Oct. 9, 1962; G. Keith Funston, President, Nev York Stock Exchange, Oct. 5, 1962; Edwin A. Etherington, President, American Stock: Exchange, Oct. 12, 1962; Albert Pratt, Investment Bankers Association of America, Oct. 8, 1962 ; O. Vance Fasbourg, Special Committee on Securities Regulation, New Yorls City Bar Association, Sept. 27, 1962.

63. See para. (a) of proposed Rule 15c2-6, supra note 59.

64. During the first quarter of 1963 there were more than 100 issues listed on the New York Stock Exchange and more than 400 on the American Stock Exchange which sold for $\$ 10$ or less. N.Y. Times, April 2, 1963, p. 62, 64, 68 (Exchange Transactions sections).

65. By, for example, offering securities in units of two or more shares at a price of $\$ 11$ per unit.

66. Of course, issuers of $\$ 10$ and under securities can avoid the rule by recapitalizing the offering their shares at over $\$ 10$. Thus they would be forced to choose between subjection to the rule at below $\$ 10$ prices and selling at higher prices which will be, perhaps, less attractive to investors.

67. See para. (d) (1) of proposed Rule 15c2-6, stpra note 59. 
The first class of exemptions concerns securities for which the information a purchaser might desire has been made available. Thus, "a security registered under the Securities Act of 1933, which is offered or sold at a time when delivery of a prospectus is required" 68 is exempt, as are securities which both have shown a "net income in [their] most recent fiscal year" reporting to the SEC under the Exchange Act or Public Utility Holding Company Act requirements or are reported on to a similar degree in a recognized securities manual. ${ }^{70}$ The proposed rule does not demand pre-sale disclosure of information required to be available $;^{71}$ but it does have the effect of assuring that the information will be generally available prior to sale-in itself an inhibition to fraud-and the rule assures as minimum protection either that the purchaser will receive the information soon after sale in the form of a prospectus, or that the security has a recent history of soundness. In effect, all stocks listed on national exchanges are exempt ${ }^{72}$ if they satisfy the net income requirement. In the absence of a strict rule of pre-sale disclosure, the net profit test compensates somewhat for the fact that mere listing offers no certainty that the security is an untainted investment. ${ }^{73}$ Since all transactions executed on national exchanges are exempted from the bookkeeping requirements, ${ }^{74}$ the regulation affects principally over-the-counter issues, which are particularly likely to be subject to fraud.

The prospectus and net income tests are not beyond criticism. Companies which are exempt from filing reports with the SEC and companies which fulfill the reporting requirements, ${ }^{75}$ but have suffered one lean year among the fat, might find their prospects and ability to obtain new capital by stock issue unrealistically darkened by the rule's effects. Such criticism might be avoided by

68. Id. at para (a) (4).

69. Id. at para. (a) (1) (A).

70. Id.at para. (a) (1) (B).

71. Under $\$ 5$ of the Securities Act of 1933, 48 Stat. 77 (1954), as amended, 15 U.S.C. § 77e (1958), sales may be made without the seller being required to furnish the buyer with a prospectus in advance, so long as the prospectus accompanies or precedes delivery of the security after the sale.

72. Since all listed securities must file reports pursuant to Sections 13 or 15 (d) of the Securities Exchange Act, 48 Stat. 896, 897 (1934), 15 U.S.C. $\$ \S 78 \mathrm{~m}, 780$ (d) (1938), satisfying the requirements of paragraph (a) (1) (A) of the proposed rule, stipra note 59.

73. Ownership and the financial setup of a company can change overnight. "We live in an age of mergers, where shifts of control may take place quickly through such devices as a negotiated purchase, a sale of assets, a merger, or a stock acquisition." Jennings, The Role of the States in Corporate Regulation and Investor Protection, 23 LAW \& ConTEMr. Proв. 193, 217 (1958). Great Sweet Grass and Bon Ami are pertinent examples of listed securities involved in boiler room transactions. Great Sweet Grass was listed on the American Stock Exchange in 1955, Great Sweet Grass Oils Ltd., 37 S.E.C. 683, 685 (1957), and Bon Ami was listed on the New York Stock Exchange in 1956, Wise, The World of Alexander Guterma, Fortune Magazine, Dec. 1959, 144, 154. Guterma, responsible for several boiler room operations, was the chief executive officer of three corporations listed on the New York Stock Exchange. Id. at 145.

74. See para. (d), exemption (1), of proposed Rule 15c2-6, supra note 59.

75. Id. at paragraph (a) (1) (B). 
simple amendments of the rule, making it clear that exemptions exist where prospectus-like statements are voluntarily filed and made available to purchasers, ${ }^{70}$ or changing the net income test to provide exemption for firms which have shown a profit trend for a longer term-say, three of the preceding four years. On the other hand, this class of exemption may also be subjected to criticism as too inclusive, in the sense that it fails to distinguish between cases where the client receives the information before completing the transaction and those where he does not. But the possibility that boiler room type transactions, exempted from the rule despite the non-disclosure prior to sale, will occur is lessened because of the availability of information through other sources; $;$ moreover, in such transactions, because the seller must have the information at hand, prosecution would be easily available under Section $17(a),{ }^{78}$ the anti-fraud provision of the Securities Act. To put conclusive stress on actual pre-sale communication of the information disclosed might be to put unrealistic strictures on broker behavior and to resurrect problems of proof in a new and possibly more difficult guise.

The second class of exemptions excludes from operation of the rule all transactions involving clients who would not seem to require its protection : brokers, dealers, financial institutions ${ }^{79}$-including insurance companies and pension, welfare or profit-sharing funds-and "regular customers," 80 defined as "any person with whose written agreement the broker or dealer is maintaining a general account or special cash account as provided in Regulation $T$, and who has purchased securities in two or more different issues at different times during the past year from or through [him] ... unless such purchases have been solicited to avoid the operation of this rule." 81 By requiring a past course of dealing between the broker and investor, the "regular customer" exemption recognizes that in these circumstances the broker will have become familiar with his client's financial situation, and, conversely, that the client will have achieved some investing sophistication through his previous market experience. Not only, then, is it more likely that a telephoned transaction will be part of a regular course of business; it is also less likely that the client will be deceived. Although others may well possess financial sophistication, it does not seem that the "regular customer" exemption could be meaningfully broadened to include them without including large numbers of purchasers to whom the inference could not fairly be applied.

The third class of exemptions relates to those transactions where origin or

76. Even though an issuer might claim an exemption from registration, it is SEC policy to allow him to register an issue as long as he complies with the registration requirements. (Letter from Irving M. Pollack of the Securities Exchange Commission to the Yale Lotv Journal, May 31, 1963.

77. I.e., access to a prospectus or "recognized securities manual."

78. 48 Stat. 84 (1933), as amended, 15 U.S.C. $\S 77 q(a)(2)(1958)$. See text at note 40 supra.

79. See para. (a) of proposed Rule 15c2-6, supra note 59.

80. Ibid.

81. Id. at para. (c) (2). 
frequency suggest that boiler room techniques are not involved: transactions not solicited by the broker or dealer $;{ }^{82}$ "isolated transactions not a part of any concentrated sales effort", 83 and transactions which the Commission rtiles, upon request, not to be within the purposes of the rule. ${ }^{84}$ These are apparently designed not only to exempt circumstances in which the cost of enforcing the rule would exceed the utility of enforcement, but also to reduce the uncertainty felt by the honest broker who will inevitably find himself involved at times in apparently covered transactions.

Yet these rules, in conjunction with the overall prohibition of telephone transactions in non-exempt stock, may tend to increase uncertainty to some degree, for they raise difficult questions about the inclusiveness of the phrase "offer or sell . . . by telephone."8s It seems clear that standard boiler room sequences involving mail along with telephonic solicitation are to be included within the rule, if ready evasion is to be prevented. Thus, a brochure pursued by a telephone follow-up by the broker, or a brochure which serves to excite the client to call the broker himself would seem to fall within its scope. This seems to reduce the exemption for unsolicited transactions to situations in which the broker acts as no more than an order clerk. He might have serious doubts about the advisability of cautioning or advising the client who has called him about a purchase, since such action might turn an unsolicited transaction into a solicited one; even the transaction executed by telephone after a face-to-face conference with a client might be subject. The most beneficial as well as the most scurrilous of professional practices might thus be curbed. But the possibility that some beneficial transactions will result from customer initiated transactions would not compel all customer initiated calls to be exempted. There is still the danger that brochures, while non-violative of the anti-fraud provisions, may be a potent enough "come-on" to engender the evil the proposed rule is designed to control. And narrow construction of the "unsolicited transaction" exemption does not foreclose exemptions for non-fraudulent transactions under other rubrics.

The exemption of "isolated transactions not a part of any concentrated sales efforts" is ambiguous, insofar as "isolated transactions" may be distinguishable from those which are "part of a concentrated sales effort." If the isolated nam ture of the transaction is to be given special weight, it is probable that only transactions in non-exempt issues inadvertently made, or where the exemption status of the transaction is ambiguous will be excluded from operation of the proposed rule. By placing greater emphasis upon the phrase "not a part of any concentrated sales effort," however, increased freedom for legitimate transactions would seem to be secured. So long as the broker refrains from the aggressive repetitiveness common to all boiler room operators, he will probably be exempt from the rule thus interpreted. A substantiality test which

82. Id. at paragraph (a) (3).

83. Id. at para. (a) (2).

84. Id. at para. (b).

85. Id. at para. (a). 
permitted low-intensity solicitation of unknown persons, ${ }^{80}$ in recognition of the broker's traditional method of stimulating his trade, is also inferrable from the exemption. Such an interpretation, resolving the exemption's ambiguity in favor of broker protection, might seem to involve a return to the proof diffculties attending present, non-rule enforcement. Since brokers engaged in these transactions would not be exempt from the record-keeping requirements, however, the SEC would have ready access to substantive indicia of the concertedness of their efforts. Ambiguities with respect to the quantum of substantiality would seem easily resolved by a program of publication and warning. Thus, emphasis on the degree of concentration of a sales effort as an exemption criterion-going to the heart of the objectionability of the boiler room and the characteristic most essential for its success-would seem a fruitful means of narrowing the potential overreach of the rule.

Similar benefits might be realized from a broad interpretation of the exemption "excusing" from the rule transactions cleared by the Commission in advance. A literal reading, suggesting that clearance must be obtained for each sales transaction, renders this exemption nugatory. A reading which would entitle the SEC to exempt on the basis of the stock involved would seem to contradict its policy against commenting on the suitability of particular issues. ${ }^{87}$ But seemingly possible is a reference to forms of transaction-the most obvious is the face to face discussion which may be followed up by telephone-which the SEC could certify as being outside the purposes of the rule. Certainly, exemptions ought to be available for sales techniques utilizing the telephone but not presenting the dangers of boiler room operations. If the exemption can not be read to this effect, it would seem that it should be amended to do so. Again, proof difficulties introduced do not seem particularly great; in the example chosen, the fact of face-to-face contact indicates that there will be little cost and difficulty in obtaining the purchaser's testimony in proceedings against the broker, as well as little likelihood of need to do so.

In sum, the exemptions are susceptible of a reading which seems to meet most of the objections to the broad reach of the rule. Remaining within its prohibitive effect would be concentrated sales transactions by telephone directed towards inexperienced, unknown persons and involving unreported or financially insecure securities selling at less than $\$ 10$. This would seem an apt description of the boiler room technique; outside of a few uncertainties probably resolvable in the suggested manner, its application to any particular transactions seems clear.

86. It could be argued that boiler room operations, which depend upon "cold" telephone sales for success, would not survive, while legitimate broker-deslers would be only minimally affected. Of course, boiler room activities can be carried on successfully by securities establishments which transact the majority of their business outside the reach of the proposed rule. 'Even though most big time 'boiler rooms' have been put out of business, ... their kind of hardselling practices areb eing used by securities concerns 'purported to be respectable.' Wall Street Journal, May 21, 1962, p. 5, col. 2. Even highly reputable firms have engaged in boiler room practices. For a report of the activities of one Merrill Lynch, Pierce, Fenner \& Smith branch office, see note 31 supra, para. 2.

87. See note 97 infra. 
The record keeping provisions ${ }^{88}$ of the rule, however, have a broader impact, imposing extensive bookkeeping burdens with respect to telephone transactions in equities in the less than $\$ 10$ range. Their main thrust is toward facilitating investigation and overcoming the problem of proof. An SEC rule already provides that registered brokers must maintain certain books and records, including an itemized daily record of all transactions, ${ }^{80}$ but the existing rule requires no data on offers, addresses, phone numbers, solicitations, or dates for completed transactions. Proposed Rule 15c2-6 requires not only this information, but also a notation of the origin of the phone call (whether broker or customer), copies of lists used to identify customers or prospective customers, and copies of toll slips for all telephone calls made by the broker or dealer. This additional data would provide the Commission with more evidence during a prosecution; the records of offers, moreover, might aid investigators in halting a boiler room campaign before any fraudulent transactions had been completed. The provision seems sufficiently complete to frustrate attempts at evasion, readily revealed through phone bill-toll slip discrepancies; the more extensive bookkeeping requirements may also lead to more conscientious performance by salesmen in their dealings with customers. On the other hand, it seems reasonable to infer that the interference to which the requirements may give rise could substantially slow the pace of sales activity in the securities industry-an effect not necessarily limited to the under $\$ 10$ equities which are directly affected. The extent of this impact is admittedly speculative; yet the necessity of the bookkeeping requirements, if the proof advantages of the rule are to be obtained, calls for careful consideration in evaluation of the entire program.

Exemptions alleviate the most severe problems of the bookkeeping provision. Transactions on national exchanges, transactions in newly issued securities for which prospectuses are available, and transactions with brokers, dealers, and institutional and regular customers are wholly exempted.90 The absence of a bookkeeping exemption for unsolicited, isolated, inadvertent and excused transactions ${ }^{91}$ is readily explained by the necessity of obtaining evidence to prove that any questioned act is within the relevant transaction exemptions. Bookkeeping exemptions for traded securities are not based on the disclosure and income criteria of the offer or sale exemption, ${ }^{02}$ but go only to transactions on national exchanges. This difference may embody a recognition of the burden bookkeeping requirements would put on the immense daily flow of business in stock traded on the national exchanges and of the small likelihood that strccessful boiler rooms are operating through exchange transactions.

Even with the burden thus narrowed, the combined effect of record keeping

88. See para. (d) of proposed Rule 15c2-6, stipra note 59.

89. 17 CFR 240.17 (a) -3 (1949).

90. See para. (d) and exemptions (1) and (2) thereto, proposed Rule 15c2-6, supra note 59.

91. Which transactions are exempted from the offer and sale portion of the rule, id. at paras. (a) (2), (a) (3), and (b).

92. Id. at paras. (a) (1) and (a) (4). 
requirements and transaction prohibitions may indicate that the probability of success in eliminating boiler room operations is not worth the price of inhibitions upon those legitimate market transactions which depend upon speed and informality for their success. The difficulties of the proposed rule arise from its focus upon physical events rather than the fraudulent nature of transaction; its exemptions pinpoint the market area in which boiler room activity is most likely to occur, but then fail to distinguish between those transactions which in fact honestly fulfill disclosure requirements and those which, in the manner of all frauds, do not. The extent of the problem thus posed cannot be said to be demonstrated beyond the level of plausability on the basis of available facts, but the vigorous critical reaction which the measure has received in reputable financial circles and the ambivalence of SEC espousal suggest that however leniently the rule would be interpreted, it would present serious curbs on legitimate conduct.

\section{Alteratives to the Proposed Rule}

Partially reflecting its own uncertainty regarding the proposed rule, the SEC in April transferred to Congress a large share of the burden of inquiring into devious securities marketing techniques. ${ }^{23}$ Presumably, the proposed rule will be under congressional consideration, and no doubt concurrent or alternative methods of controlling boiler room type activities will also be studied. or $^{\text {s }}$ Rather than focusing on certain incidents in the flow of securities business, as the proposed rule does, the problem might be approached at other points-by placing emphasis on the riskiness of particular issues, the needs of particular customers, or a reinvigoration of the disclosure concept. But any alternative, such as directing attention at issues, customers, or disclosure, must be evaluated in the context of the proof difficulties which have led the SEC to the radical approach of the proposed rule. If increased efficiency of anti-boiler room administration is unobtainable or obtainable only at too high a price it may be necessary to return to a functional emphasis, which contemplates the solution of proof problems only to the extent consistent with an avoidance of undue enlargement of the regulatory net.

93. An extensive report of market abuses, prepared by an SEC Committec and focusing upon shortcomings in the securities industry and in the self-regulatory authorities, was referred to Congress for analysis and hearings, SEC, Special Study of Securrties MarsKETS, chs. I-IV, IX (April 3, 1963) ; N.Y. Times, April 4, 1963, p. 1, col. 4; Wall Strect Journal, April 4, 1963, p. 3, col. 1. See also the Commission's endorsement of the Committee's recommendations, SEC, Special Mlarket Study Release No. 25, April 30, 1963; N.Y. Times, April 30, 1963, p. 1, col. 4.

94. If the rule proposed by the SEC fails to be adopted, it will not be the first time that a sweeping regulation suggested by the Commission did not become effective. A rule proposed in 1942 by the Commission which would have required every dealer exceuting a purchase or sale over-the-counter to disclose the best independent bid and asked price ascertainable was, upon later consideration, shelved by the SEC. SEC Securities Exchange Act Release No. 3940, April 2, 1947. This proposal was dusted off last month and presented in a new form, N.Y. Times, Mlay 5, 1963, p. 46, col. 4. 
One possible modification of the proposed rule would be to empower the SEC, like some state commissions, ${ }^{95}$ to select on the basis of their promotional or highly speculative nature which issues would be subject to the burden of a boiler room regulation. Such selection might appear to be no more than an extension of the principle by which profit-making stocks were selected for exemption ${ }^{96}$ But inquiry into the substantive character of particular issues would involve the SEC in a form of legitimation which does not go directly to the issue of fraud. And whatever the merits of such state control, the basic philosophy of the federal securities acts is one of disclosure, not of stubstantive regulation. ${ }^{97}$ Not only does the SEC not pass upon the merits of securities, but it is a crime for an issuer to suggest that it has approved his securities..$^{\text {g8 }}$ Passing on the merits is too much like a guarantee; even the soundest of stocks is subject to watering by high pressure techniques, ${ }^{00}$ and SEC substantive selection would in no way curb this. There are sound policy bases in a free market economy for reluctant exercise of paternalistic concern beyond the degree necessary to render the investor equal to the choices he must make. Louis Loss has already suggested what might be the general reaction to SEC substantive regulation: "For myself ... I shudder at the thought of giving a federal agency life-and-death power over virtually the entire inclustry of the country by subjecting all public financing to such vague tests as 'fair, just and equitable' or 'sound business principles.' "100

95. See 1 Loss, Securities Regulation 56 n.149 (2d ed. 1961). One of the most extreme examples of substantive regulation is the California statute, Cat. CoRp. CodE $\$$ 25500. No company may offer or sell its stock, with certain exceptions, until it has first applied for and secured from the Corporation Commissioner a permit authorizing it to do so. Ibid. Permits are issued only after the Commissioner has determined

that the proposed plan of business of the applicant and proposed issuance of securities are fair, just, and equitable, and that the applicant intends to transact its business fairly and honestly, and that the securities that it proposes to issue and the method to be used by it in issuing or disposing of them are not such as, in his opinion, will work a fraud upon the purchaser...

CAL. CoRp. Code $\S 25507$. At least fifteen states apply the "fair, just, and equitable" standard. 1 Loss, op. cit. supra.

96. See para. (a) (1) (A) of proposed Rule 15c2-6, supra note 59.

97. See generally 1 Loss, Securities Regulation 121-131 (2d ed. 1961).

98. An SEC rule requires that a caveat be printed in large capital letters on the front cover of every prospectus:

THESE SECURITIES HAVE NOT BEEN APPROVED BY THE SECURI. TIES AND EXCHANGE COMMISSION NOR HAS THE COMMISSION PASSED UPON THE ACCURACY OR ADEQUACY OF THIS PROSPEC. TUS. ANY REPRESENTATION TO THE CONTRARY IS A CRIMINAL OFFENSE.

Securities Act of 1933, Reg. C, Art. 2, Rule 425.

99. See note 73 supra.

100. Loss, The Role of Govermment in the Protection of Investors, Address delivered at the Mexico Stock Exchange, June 6, 1957, p. 12. "Fair, just, and equitable" is the test applied in at least fifteen states. 1 Loss, op. cit. supra note 95 , at 56 n. 149. 
A second alternative approach, elements of which are present in the "regular customer" concept of the proposed rule, would stress suitability of particular shares for particular customers. The suitability approach, now under study by the SEC and Congress, ${ }^{101}$ is already in force under Article III, Section 2 of the National Association of Securities Dealers Rules of Fair Practice:

In recommending to a customer the purchase, sale or exchange of any security, a member shall have reasonable grounds for believing that the recommendation is suitable for such customer upon the basis of facts, if any, disclosed by such customer .... as to his financial situation and needs. ${ }^{102}$

The concept appears to impose three duties upon the broker: to know his customer, ${ }^{103}$ to know the securities, ${ }^{104}$ and to accommodate the one to the other. The SEC has both recognized its relevance and shown its potentialities for boiler room regulation in stating that its clear purpose

would be defeated if it were construed as permitting a broker or dealer to engage in a practice of recommending low price speculative securities to unknown customers-a practice which by its nature involves a high probability that the recommendation will not be suitable to at least some of the persons solicited-without any knowledge of or attempt to obtain information concerning the customer's other security holdings, his financial situation, and his needs so as to be in a position to judge the suitability of the recommendation. ${ }^{105}$

As far as the SEC is concerned, then, the salesman ${ }^{100}$ has an affirmative duty under the NASD rule. The broker or dealer should not merely merchandise a product: he must at least "attempt to obtain" the information from the customer, fulfill the implicit duties to know the security, its financial status and prospects, and to evaluate the investor's financial needs, recommending only those securities which there are "reasonable grounds" to believe will fit those needs.

While a bookkeeping rule-requiring broker records on the customer's occupation and investment goals-would facilitate enforcement, as the Commission recently suggested, ${ }^{107}$ the objections to a suitability approach go be-

101. SEC, Spectal Study of Securities MAarkets, ch. III B, 147, 148, 183, 186 (April 3, 1963) ; N.Y. Times, April 4, 1963, p. 40, col. 4; April 30, 1963, p. 42, col. 8.

102. Gerald M1. Greenberg, SEC Securities Exchange Act Release No. 6320, July 21, 1960, p. 3, n. 5. The National Association of Securities Dealers, Inc. will hercinafter be referred to as NASD.

103. Ibid.; Boren \& Co., SEC Securities Exchange Act Release No. 6367, Sept. 19, 1960.

104. Both duties are referred to in the recent SEC report, SEC, Specini Srudy of Securities Mlarkets, ch. III B, 147-48 (April 3, 1963). Cf. Anderson v. Knox, 297 F.2d $702,711-20,725-27$ (9th Cir. 1961), a case involving an insurance agent who peddled a policy in "reckless disregard" of its suitability for a particular customer.

105. Gerald M. Greenberg, SEC Securities and Exchange Act Release No. 6320, July 21,1960, p. 6 .

106. The terms salesman, broker, or dealer could be used interchangeably. The respo:sibility would belong to whoever contacts the customer.

107. SEC, Spectal Study of Securities MAarkets, ch. III B, p. 186 (April 3, 1963); N.Y. Times, April 30, 1963, p. 42, col. 8. 
yond the obvious difficulties of proof; in particular it seems to present problems identical to those of the "selected security" approach. ${ }^{108}$ Thus, what constitutes "reasonable grounds" would remain uncertain until expounded by the Commission and courts in case-by-case adjudication. Although it might seem reasonable for a broker to recommend a "safe" security to a customer who cannot afford speculation or to recommend a "risk" security to a customer willing and financially able to gamble, ${ }^{109}$ the basis of such judgments as "safe," "growth," "risk," and "financially able" depend upon the broker's expertise. If the SEC can find no standards to evaluate the broker's judgment of "suitability," other than his "reasonableness" or "good faith," then an SEC determination of "unsuitability" would be merely a post hoc substitution of the Commission's value judgment for the broker's. Thus, the SEC would, again, be forced to make value judgments about the merits of a security, and would have to engage in the difficult task of evaluating the broker's recommendations to his customer, or the good faith of his possibily frustrated inquiry into the consumer's needs. Although such rules may be appropriate for self-regulatory professional associations such as the NASD, they do not seem appropriate for SEC adoption. And that the SEC compels the NASD to administer the rule for it, ${ }^{110}$ in light of the Commission review which would then attach, ${ }^{111}$ does not seem to answer this objection.

If the proof advantages of the proposed rule would be, as feared, purchased only at too dear a price, the most fruitful approach to the boiler room problem and the professional malaise which it signifies may well be a reinvigoration of the disclosure concept through careful definition of the professional's responsibility under the anti-fraud provisions of the Securities Acts. ${ }^{112}$ Such a development would stress investigation and transmission, at least in brokerdealer solicited transactions, ${ }^{113}$ since disregard of those duties is the source

108. See text at note 97 sipra.

109. Reputable broker-dealers probably follow such general guidelines. For instance, expert witness Harold E. Wood, a Minnesota investment banker and one time head of the National Association of Securities Dealers, told a federal court that in his experience there were three types of customers:

One is the person who wants ... safety of income. ... [ [H] e can't afford speculation. ... And then you have the customer who is not interested in income. He has plenty of outside income. He is interested in growth, so he buys the type of stock like Minnesota Mining, and then you have a third type of person who is. say the businessman who can afford to take a risk; and he says, I want to buy, not a quality growth stock or an income stock of quality, I want to gamble. And he is the sort of person to whom you sell Texota, for example....

Transcript of Proceedings, p. 56, United States v. Pandolfo (D. N.D. Sept. 28, 1959).

110. N. Y. Times, May 5, 1963, Sec. I, p. 1, col. 2.

111. 52 Stat. 1073 (1938), 15 U.S.C. $\& 780-3(\mathrm{~g})$ (1958).

112. Primarily $\& 17$ (a) of the Securities Act, 48 Stat. 84 (1933), 15 U.S.C. 77q(a) (2) (1958). See note 40 supra.

113. For proof purposes, the SEC report recommends that a rule be adopted requiring "that every retail transaction be designated 'solicited' or 'unsolicited' in the permanent records of a broker-dealer; that all customer complaints be kept in a single file and available 
of boiler room success. ${ }^{114}$ A pair of recent SEC decisions demonstrate the shape such a development might take. In Mac Robbins \& Co.115 the SEC suspended two securities salesmen who had been involved in a boiler room operation and had failed to disclose easily ascertainable adverse information about the stock promoted. ${ }^{116}$ The Commission held that the salesmen were obligated to familiarize themselves with sales materials distributed by their employer ; furthermore, if these materials appear upon their face to be incomplete or an unfair presentation of the significant facts respecting the security offered ${ }^{117}$ the salesmen could not rely upon the information. The decision in Heft, Kahn \& Infante, Inc. ${ }^{118}$ put similar responsibilities upon the research

for inspection and examination by the Commission, the NASD, and the exchanges . ..." SEC, Spectal Study of Securities Markets, ch. II B, p. 186 (April 3, 1963).

114. The SEC report to Congress, SEC, Spectal Study of Securitres Markets, (Apri1 3, 1963), made extensive recommendations designed to increase investor protection in the securities markets, including higher standards of investigation and disclosure, id. at ch. III B, p. 187 (broker-dealer review of "available officially filed data prior to recommending or selling specific securities"); ch. IV C, p. 26 (broker-dealer disclosure to customers of information concerning unregistered distributions, including the amount of securities, whether inventory or investment stock, and the offering price and underwriting arrangements) ; ch. IX B, p. 128 (extension of reporting requirements of the Exchange Act to issuers of unlisted securities).

Among other recommendations were the following: compulsory membership in a sclfregulatory body for all broker-dealers and investment advisors subject to Commissioner jurisdiction, higher standards for entry into the securities business for both firms and individuals, delegation of power to the SEC to bring administrative proceeding directly against individuals involved in violations without first proceeding against the firm, id. at ch. II F, pp. 19-24; tightened supervisory responsibilities of firm personnel and self-regulatory agencies, salesmen compensation less dependent on production, id. at ch. III $\mathrm{B}$, pp. 185-88; increased attention to investment advisory practices, id. at ch. III C, pp. 120-22; extension to 90 days of the period during which all dealers are required to deliver prospectuses in the case of most "first" issues of common stock, id. at ch. IV B, p. 162. See also SEC, Special Market Study Release No. 25, April 30, 1963.

115. SEC Securities Exchange Act Release No. 6846, July 11, 1962, off'd Berloo v. SEC, No. 27774, 2d Cir., April 9, 1963.

116. Brief for Petitioner, p. 9, Berko v. SEC, stpra note 115.

117. Mac Robbins \& Co., stipra note 115 , at 12 ; Berko v. SEC, supra note 115 , at 1634. Both decisions were based on the fact that Berko knew or should have known he was operating out of a boiler room. Ibid. Neither the Commission nor the Second Circuit characterized the duties of a salesman in "a legitimate operation":

Whatever may be a salesman's obligation of inquiry ... where securitics of an established issuer are being recommended to customers by a broker-dealer who is not engaged in misleading and deceptive high-pressure selling practices, that situation is not presented here.

Mac Robbins \& Co., supra at 12.

The Commission acted well within its mandate in concluding that the 'public interest' requires that a salesman working out of a 'boiler room' be held to a higher duty to prospective customers than a salesman working out of a legitimate sales operation....

Berko v. SEC, supra at 1634-35.

118. SEC Securities Exchange Act Release No. 7020, Feb. 11, 1963. 
staff of a broker-dealer, 119 concluding: "in his fabulist role [the analyst's] activities were no less reprehensible and no less willful," than if a salesman had made similar statements orally; "indeed, the market letter was designed to reach a much wider audience than the oral statements of a salesman."120 Thus, the suggestion was made that brokerage employees at all levels share duties of both investigation and transmission of information under the anti-fraud provisions.

Stressing high standards reflecting the quasi-professional status of the securities field may seem to present considerable problems since it carries the concept of fraud beyond its normal reaches, even in SEC enforcement, ${ }^{191}$ through an affirmative requirement of investigation. Inflexible respect for these standards might burden the industry as heavily as the bookkeeping requirements of the proposed rule, and problems of proving infractions will be more severe than those under the SEC proposal, although perhaps less stringent than under the anti-fraud rules, if the elements of investigation and disclosure are clearly defined. However, the problems of selecting what is material to investigation and to disclosure are not inconsiderable. Certainly brokers cannot be expected to maintain as complete a picture of the issuer as the issuer's accountant, nor to disclose as much information as is required by an SEC prospectus. It seems clear that such characteristics of a security as the financial status and dividend policy of the issuer should be investigated. Data required by the SEC in a registration statement ${ }^{122}$ and information published by investment advisory services would be pertinent, including the issuer's productivity quotient, managerial experience, and existing and potential markets. How much of this must be disclosed is limited by the resources of the securities industry and the utility of the information to the customer. Even if the inefficiency of total disclosure would not toll the end of the securities business, the bulk of data could not be assimilated by the average customer. Nevertheless, certain negative factors which would have a determinative weight in the customer's decision should be disclosed. For instance, a customer should be on notice that a recommended issuer has suffered recent losses, or a security's price-earnings ratio is high. Although losses and other apparently negative factors may be counterbalanced by favorable elements, ${ }^{128}$ the SECby listing certain factors which must always be disclosed-would provide for notice to the customer while avoiding the difficulties of substantive review of the broker's judgment.

119. Id. at 7-10.

120. Id. at 10 .

121. For a comparison of securities fraud concepts and common law deceit, see 3 Loss, Securities Regulation 1430-44 (2d ed. 1961).

122. 48 Stat. 88 (1933), 15 U.S.C. \$ 77aa (1958). The SEC report to Congress recommends that broker-dealers be obliged to consult "available officially filed data prior to recommending or selling specific securities." SEC, SPECral STUdy of SEcuritres MAriets, ch. III B, p. 187 (April 3, 1963).

123. Depending upon a variety of other factors, the security may still be a good purchase, if, for instance, the issuer was just awarded a government contract. 
If such responsibilities to investigate and disclose ${ }^{124}$ could exist in a workable system of approaching securities fraud problems generally, administrative questions would still remain concerning how contours of the duties would be clarified. A method of developing criteria for general duties of investigation and disclosure may be found in the SEC's recent release in the Volkswagonwerk: ${ }^{125}$ matter. The release called to the attention of the securities market the need to describe certain possibly negative features respecting Volkswagonwerk stock, arising out of its foreign origin. The release indicates a mode of procedure because it treats a specific situation where disclosure of certain types of facts was thought to be essential. Moreover, direction by release seems better suited than the formalistic rule-making procedure for establishing categories in which investigation and disclósure would be required. It avoids both the rigidity of rule-making and the uncertainty of case-by-case development while aiding measurably in the understanding of the elements material to investigation and disclosure. A series of releases, developing concepts of investigation and disclosure over a substantial period of time, might mediate with greater sensitivity between the freedom the market requires and the protection which seems essential to the purchaser.

124. Brokerage personnel would have separate but interrelated duties regarding investigation and disclosure. The controlling officer of a firm should bear the responsibility of primary inquiry into characteristics of the issuing company, and of distributing to his salesmen a list of possible adverse factors, which the salesman would be under a duty to disclose to customers. The salesman would be further compelled to analyze the memorandum from the controlling officer in accordance with the requirements of MFoe Robbins and Heft, Kahn \& Infante. See notes 115 and 118 supra. Because a salesman's misrepresentations can cause the loss of the firm's registration, Securities Exchange Act $\$ 15(b), 49$ Stat. 1378 (1936), 15 U.S.C. \& 780(b) (1958), controlling officers should recognize a necessity to improve training and supervision, as well as to conduct responsible investigations of issuers and disseminate complete lists of adverse factors to the salesmen.

125. SEC Securities Exchange Act Release No. 6525, April 12, 1961:

The Commission was made aware that transactions may be effected in V.W. shares in this country by a notice circulated by the Foreign Securities Committce of the National Association of Securities Dealers, Inc., which indicates among other things that V.W. shares were eligible for trading in the over-the-counter market in Germany..., that persons who purchase such shares in Germany will have no proof of ownership other than the advice "from a German counter party" that these shares have been purchased, and that the actual share certificates will probably not be available for several months.

In addition to the above, the Commission understands that information generally available for most securities traded in this country is unavailable as to V.W. shares. Statistical manuals of ordinary usage contains no mention of the company or of the shares; there is no material on file with the Commission, nor, as far as is known, with any other agency; and balance sheets, profit and loss statements, carnings, reports, etc., are not available.

Persons effecting transactions in these securities, particularly brokers and dealers, should be careful to avoid misstatements with respect to the securities and the company, and if, as appears, there is an unusual lack of pertinent information necessary to reach an informed judgment as to the value of the securities, this fact would be a material fact within the meaning of the anti-fraud provisions [of the Securities Acts]. 